\title{
A national intervention in teaching phonics: a case study from England
}

Article

Accepted Version

Stainthorp, R. (2020) A national intervention in teaching phonics: a case study from England. The Educational and Developmental Psychologist, 37 (2). pp. 114-122. ISSN 20590776 doi: https://doi.org/10.1017/edp.2020.14 Available at https://centaur.reading.ac.uk/93935/

It is advisable to refer to the publisher's version if you intend to cite from the work. See Guidance on citing.

To link to this article DOI: http://dx.doi.org/10.1017/edp.2020.14

Publisher: Cambridge University Press

All outputs in CentAUR are protected by Intellectual Property Rights law, including copyright law. Copyright and IPR is retained by the creators or other copyright holders. Terms and conditions for use of this material are defined in the End User Agreement.

\section{www.reading.ac.uk/centaur}

\section{CentAUR}

Central Archive at the University of Reading

Reading's research outputs online 


\section{A national intervention in teaching phonics: A case study from England}

\begin{tabular}{|r|l|}
\hline Journal: & The Educational and Developmental Psychologist \\
\hline Manuscript ID & EDP-OA-2020-0014 \\
\hline Keywords: & Phonics teaching, Word reading \\
\hline Abstract: & $\begin{array}{l}\text { This paper presents an analysis of national performance in reading from } \\
\text { England throughout the 21st century. At the start of the century the } \\
\text { teaching of literacy in primary schools was conducted within a framework } \\
\text { guided by a National Literacy Strategy recommending a model of reading } \\
\text { called 'The Searchlights Model'. Early on it came to be clear that the rise } \\
\text { in levels of performance predicted from adoption of this strategy limited. } \\
\text { This led to a review of the effective teaching of early reading (Rose, } \\
\text { 2006). Rose recommended that the Simple View of Reading (Gough \& } \\
\text { Tunmer, 1986) be adopted as a framework. It also recommended that } \\
\text { pupils be taught how to read words in the first instance through the } \\
\text { adoption of programmes of systematic synthetic phonics. A change in } \\
\text { government reinforced this policy and added a national programme of } \\
\text { early assessment of grapheme-phoneme knowledge. These changes } \\
\text { uncovered an important issue: namely that subject knowledge for } \\
\text { teaching phonics effectively was limited. Steps have been taken to } \\
\text { mitigate this. The most recent data from the PIRLS 2016 study suggest } \\
\text { that England is now beginning to close the achievement gap with the } \\
\text { pupils in the lowest percentiles making the most improvement. }\end{array}$ \\
\hline
\end{tabular}

\section{SCHOLARONE Manuscripts}


A national intervention in teaching phonics: A case study from England

This paper presents a case study of changes in the literacy education landscape of England mainly over the last two decades. It charts the progress towards a national approach to teaching systematic synthetic phonics as the first approach to teaching children to read words. This is an intervention for all.

Literacy levels often make headline news, so it is important to take a step back and look at the evidence objectively. Brooks (1997) pointed out that standards in Britain between 1948 and 1996 had been maintained. There had been no significant fall. The achievement levels of the middle to high performing pupils were comparable with the rest of the world.

However, there was a considerable tail of underachievement which had persisted for decades. The developments reported here are mapped against national performance statistics, and levels of attainment achieved by English pupils taking part in international studies. The jurisdiction of interest is specifically England because education is devolved to the individual countries of the United Kingdom.

The premise of education policies on literacy should be that all experience high quality, effective teaching that enables them to achieve skilled, accurate fluent reading skills, which they carry with them throughout their education and life. It would be naïve to ignore the fact that politicians become involved in educational practice. However, the story presented here does not relate to any specific government. There has been remarkable consensus on the potential for phonics teaching to benefit particularly those children who are at risk of failing to achieve acceptable levels of literacy.

The timeline presented in Figure 1 is provided as an aide memoire for plotting events over time.

[insert Figure 1 about here] 
One of the most significant developments in education England in the late $20^{\text {th }} \mathrm{C}$ was the 1988 Education Reform Act. This established a National Curriculum (NC) to be taught by all state-funded schools. It included naming school phases and teaching years. There are now four Key Stages of education defined in relation to the ages of pupils in each year. Key Stage (KS) 1 covers Years 1-2 for pupils ages5-7 years; KS2 covers Years 3-6 for pupils ages 7-11 years; KS3 covers Years 7-9 for pupils age 11-14 years; and KS4 covers ears 10-11 for pupils aged 14-16 years. Prior to KS1 there is a Foundation Stage for 2 years covering nursery and reception classed for pupils ages 3-5. The final part of the foundation stage is compulsory with its own Early Years Foundation Stage framework, which is separate from but designed to feed into the NC.

\section{National Curriculum for English}

The curriculum of interest for this paper is the NC for English. Since its inception, the curriculum for English as a subject has included the teaching of literacy, notwithstanding the fact that reading and writing are skills that cross the whole of the curriculum rather than being academic subjects in their own right. The first curriculum and programmes of study (PoS) were published in 1988, followed by updates in 1995, 1999, in 2013 (see Appendix A for the last two PoS). The curriculum documents cover the PoS, which are statutory, but not the methods by which the programmes are to be delivered. Sitting alongside the statutory requirements is non-statutory guidance designed to support and augment the PoS. The preamble to the current 2013 curriculum specifically states that the PoS for KS1\&2 consists of two dimensions: word reading and comprehension. Thus, without stating it explicitly, the framework for teaching reading is the Simple View of Reading (SVR) (Gough \& Tunmer, 1986). The SVR states that reading is the product of decoding print and language comprehension skills. With the SVR as a framework, the NC now requires all children to be taught how to read words directly starting with a programme of systematic synthetic phonics. 


\section{National assessment of reading}

With the introduction of the NC, national assessments were mandated. There are assessments of reading at the end of the KS1\&2 at ages 7- and 11-years. A common scale of attainment of levels of performance from Level 1-8 for KS1-3 was as introduced. For each subject there was a descriptor for each level of performance. This was an ordinal not a ratio scale. The expectation was that pupils should achieve Level 2 at the end of KS1 and make one level of progress every two years so that at the end of KS2, before moving to secondary school, the expected Level was 4.

Characterisation of performance at the end of KS1 is the level of skill of interest here since by this stage children are expected to have mastered word reading: enabling them to move from learning to read (words) towards reading to learn.

The Level 2 descriptor for reading was:

- Pupils' reading of simple texts shows understanding and is generally accurate. They express opinions about major events or ideas in stories, poems and nonfiction. They use more than one strategy, such as phonic, graphic, syntactic and contextual, in reading unfamiliar words and establishing meaning.

Reporting attainment in levels was abolished in 2014 with 2015 being the last year that this happened. From the academic year 2015/16 attainment has been reported with reference to exemplification statements about expectations of performance at the end of each key stage.

The Expected Level of attainment at the end of Y1 is now encompassed in the following statements.

- The pupil can:

- Read accurately most words of two or more syllables 
- Read most words containing common suffixes

- Read most common exception words

- In age-appropriate books, the pupil can:

- Read most words accurately without overtly sounding and blending, and sufficiently fluently to allow them to focus on their understanding rather than decoding individual words

- Sound out most unfamiliar word accurately, without undue hesitation

- In a book that they can already read fluently, the pupil can:

- Check it makes sense to them, correcting any inaccurate reading

- Answer questions and make some inferences

- Explain what has happened so far in what they have read

Both the Level 2 descriptor and the Expected Level characterisations have just short statements about comprehension of reading with genre being listed in 1999 and inference being specifically mentioned in 2014. The major differences relate to detailing word reading skills. In the Level 2 descriptor for reading unfamiliar words there is just one sentence detailing four strategies. These are listed as equal approaches to working out the identities of words. The PoS (Appendix A) in 1999 did not specifically include teaching how to read words directly. Although there was an implication that phonics teaching should be happening through teaching about phonemic awareness and phonic knowledge, there was no direction about how was to be achieved. The $2014 \mathrm{PoS}$ is much more specific about requirements to provide a programme of phonics teaching establish skills to work out how to read unfamiliar words. The new descriptor of the Expected Level details what pupils should be able to achieve as a result of the PoS that now addresses how to read words beginning with a programme of phonics.

\section{Concerns about levels of literacy}


NC developments and associated assessments provide a backdrop to the whole country interventions that have taken place in the $2{ }^{\text {st }} \mathrm{C}$. Ofsted reports (e.g. Ofsted 1996) expressed concerns about standards of reading and approaches to teaching (The Office for Standards in Education (Ofsted) is a non-ministerial department reporting to Parliament on their inspections of state schools). Almost ten years after the introduction of the NC, in 1996 only $57 \%$ of pupils left KS2 having achieved Level 4 in reading. Translated, this meant that $43 \%$ entered secondary schools with a reading ability that would not support learning across the curriculum. Ofsted reported that phonics (when taught well) contributed to accuracy and fluency across all abilities, but such teaching was patchy. Often children were introduced to only a letter a week as an initial letter but without any allied teaching about phonemes or phonemic awareness. They also commented that teacher subject knowledge was often inadequate and not accompanied by knowledge of the empirical evidence about word reading or effective teaching.

\section{The National Literacy Strategy}

These concerns led in 1997 to a National Literacy Strategy (NLS) designed to supplement the PoS. This provided non-statutory guidance about teaching reading to be rolled out across England in1998 (DfEE, 1998).

A Literacy Hour was established for all KS1\&2 (Figure 2) meaning that all children would have at least an hour a day dedicated to being taught to be literate throughout KS1\&2.

[insert Figure 2 about here]

There was a requirement that all teachers in training should receive instruction about the strategy and a national network of NLS professions was established to support current teachers. There was a suggestion that phonics would be taught in KS1, but no requirement 
for this to be systematic. It often arose from words encountered in the whole class reading session rather than being structured or systematic.

In addition to the Literacy Hour, the NLS presented a model of reading called the Searchlights Model to act as the framework to inform teaching. The four 'searchlights' were four cueing systems said to support word identification (Clay \& Cazden, 1990) (see Figure 3). These were the same as in the descriptor for Level 2 reading.

[insert Figure 3 about here]

It is more accurate to call this a metaphor since it did not arise out of models of reading developed from empirical research into how skilled readers read words (e.g. Coltheart et al., 2001), or how children develop word reading skills (Ehri, 1999, 2002). Implied in the NLS framework was that the four cueing systems were of equal use and value. At least the inclusion of phonics as a way into word reading was a step forward and the NLS was committed to the early teaching of phonics in a discrete way. There were concerns that teachers might not have the skills or resources to do this so Progress in Phonics (DfEE, 1999), a resource for teaching phonics was published. There was also provision of a day's training about teaching phonics for approximately 20,000 Reception and Y1 teachers. This was radical because there was opposition to the introduction of phonics teaching in Reception under the belief that the children were too young for this type of activity.

Figures 4 and 5 present the percentages of pupils achieving the expected levels of reading at the end of Key Stage 1 and 2 from 1996 - the year before the NLS was introduced - to the latest performance in 2019.

[insert Figure 4 and 5 about here]

Of initial interest is the performance before, and for the first few years after introduction of the NLS. Reading levels in KS1 were below $80 \%$ prior to the introduction of the NLS and 
then rose steadily until they plateaued out at $84 / 85 \%$. Reading levels in KS2 were poorer, but there was a steady rise until 2000 when $83 \%$ achieved Level 4 . The 11 -year olds in 2000 had not received any of their initial reading instruction under the NLS, but most of their teaching in KS2 had been under the NLS with the Literacy Hour with more focused teaching. These data suggest that the strategy had been some influence for good.

A positive decision was taken to have independent evaluations made of the NLS. The Ontario Institute for Studies in Education (OISE) was commissioned to undertake this. They reported in a series of publications called Watching and Learning (Earl, et al., 2000, 2001, 2003). What emerged from these reports was evidence of high-quality leadership from NLS leaders which supported a gradual rise in standards. However, from the start they identified a need to ensure that 'the teaching force has the knowledge and skills to make the best use of NL[N]S resources in their unique school settings' (Earl et al., 2000, p.40). They were more explicit about these concerns in the second report (Earl et al., 2001). They noted weaknesses in teacher subject knowledge and an erosion of confidence as they struggled with the new and unfamiliar pedagogy which was leading to inconsistencies in implementation. These concerns were still there in the final report (Earl, et al., 2003). Their perception was that there was more of an adoption of a system rather then an understanding of effective pedagogy for literacy.

The ones day's training provided in 1999 would appear to have been tokenism. The NLS supported the importance of teaching word reading strategies, but there was no clear support for any evidence-based approach to teaching phonics and certainly no recommendation to take a systematic approach using synthetic phonics teaching.

\section{International reports into teaching reading}


Around the time of concerns in England, in the United States the National Reading Panel was formed at the request of congress. Teaching Children to Read: An evidence-based assessment of the scientific research literature on reading and its implication for reading instruction was published in 2000 (National Institute of Child Health and Human Development, 2000). There were six panels covering Alphabetics, Comprehension, Fluency, Methodology, Teacher Education and Technology/Next Steps. Of interest here is the report of the Alphabetics panel chaired by Ehri. They concluded that 'systematic phonics instruction makes a bigger contribution to children's growth in reading than alternative programs providing unsystematic or no phonics instruction' (NICHHD, 2000, 2-92). They also found that early systematic phonics teaching was the most effective. However, they found no difference in effect between different the types of phonics programs they investigated: namely small-unit synthetic programmes, large-unit programmes (e.g. onset-rime), and miscellaneous programmes.

Since the NLP report there have been further studies: e.g. Christensen and Bowey (2005), Hatcher, Hulme and Snowling (2004), Johnston and Watson (2005), that have compared teaching phonics at the phoneme level versus at the onset-rime level. These found that phonics teaching per se was effective. Christensen and Bowey found a focus on graphemephoneme correspondences was a better approach; Hatcher et al. found teaching synthetic phonics (at the level of the phoneme) was more beneficial for those children at risk; and Johnston and Watson found synthetic phonics to be effective than analytic phonics.

In 2005 the Committee for the National Inquiry into the Teaching of Literacy published its report and recommendations for how reading should be taught in Australia (Rowe, 2005). This unequivocally suggested that systematic phonics teaching is critical if pupils are to be taught to read well. They found that, where there was unsystematic or no phonics teaching, progress towards skilled reading was significantly impeded. The recommendation was that 
teachers should provide direct, systematic phonics instruction as an essential arm of a programme that supported language development, reading fluency, reading comprehension and skills in new technologies. In making this recommendation they recognised that teachers and trainees should know the evidence base for the teaching approaches and be equipped with the necessary strategies for effective teaching.

\section{The Rose Review 2006}

In terms of reviews into the impact of phonics teaching, England may be considered to have been a Johnny-come-lately. In 2005 Sir Jim Rose was commissioned to chair an Independent Review into the Teaching of Early Reading (Rose Review) (Rose, 2006). The review recommended a discrete programme of systematic synthetic phonics teaching for all children as the initial primary approach to learning to read and write words: this to be done in the context of a broad and rich language curriculum. Before the age of five it recommended that teachers provide an environment with pre-reading activities paving the way to phonics instruction.

Also recommended was that the searchlights model be replaced by the SVR as a framework to inform teachers. As with the Rowe report, Rose recommended that all schools appoint as least one member of staff who was fully able to lead on phonics work.

The review was accepted enthusiastically by the Department for Children, Schools and Families, so from 2007 onwards all primary schools were expected to include a discrete, systematic phonics programme for all children in KS1, which if necessary, would continue into the first years of KS2.

\section{Letters and Sounds}

Having accepted the recommendations of Rose for all schools to include phonics teaching, in 2007 the DCSF published Letters and Sounds: a free phonics programme. This six-phase 
programme was designed for teaching phonics throughout KS1. Unlike Progress in Phonics this is a specific systematic synthetic phonics programme.

Phase 1 introduces pupils to sound discrimination activities and develops their phonological and phonemic awareness. This is followed by Phase 2, which is designed to teach pupils grapheme phoneme correspondences and how to blend and segment with letters, so they can read simple regular words. Because of rapid teaching, after 6 weeks pupils should have learned 19 letters and sounds. The programme is informed by the characteristics of English orthography, so included in this stage are activities supporting whole-word recognition of high frequency exception words, which cannot be read accurately through application of GPC knowledge. Phase 3 is designed to last about 12 weeks when the few remaining letters and sounds are introduced followed by consonant digraphs (e.g. $<\mathrm{CH}><\mathrm{SH}>$ ) and vowel (e.g. $<\mathrm{AI}><\mathrm{OW}>$ ). By the end pupils will have been taught to represent 42 phonemes by a grapheme, to blend these into words for reading, and to segment words into component phonemes for spelling. Phase 4 is short phase of 4-6 weeks designed to consolidate knowledge and secure blending for reading and segmenting for spelling. In Phase 5 pupils are introduced to the many 2- and 3-letter graphemes that have alternative pronunciations to the canonical correspondences learnt in the earlier phases. By the end of pupils are expected to be able to read hundreds of words independently. These should be both regular words on which they have applied their phonics knowledge many times; and exception words that have been learnt by rote. They are expected to have become expert in decoding words quickly and silently through well established sounding and blending routines. And finally, they are expected to decode aloud to support word identification where they recognise that silent decoding has not worked.

Phase 6, designed for Y2, is one of consolidation to build up speed, and accuracy in word reading. L\&S is a programme for teaching how to read words to establish the word reading 
skills element of the SVR. It also recommends that pupils have a rich diet of reading books independently and with support, and that they listen to experienced readers reading aloud from a wide variety of texts.

In addition to the phases, L\&S recommends an approach to teaching based on a sequence of teaching for each lesson which is recognised as best practice. Namely: introduction $\rightarrow$ revisit and review $\rightarrow$ teach $\rightarrow$ practise $\rightarrow$ apply $\rightarrow$ assess learning against criteria. There are suggestions for teaching activities and resources that teachers can make themselves but no commercially produced materials. The requirement for assessment is for teacher to monitor progress in order to provide support for all children. This monitoring provides them with objective evidence where pupils fail to make progress. This invaluable information for consultations with educational psychologists.

Following the requirement for schools to include a structured programme of systematic phonics, publishers produce programmes and resources for schools to buy in addition to the freely available L\&S. In 2010, the Department for Education published a set of core criteria which defined effective systematic synthetic phonics programmes (DfE, 2010). Schools are free to choose, but they are advised to map the programme against these criteria. L\&S meets all the criteria and is still very widely used by schools despite the commercially available programmes (Flynn, Stainthorp, Powell \& Stuart, submitted).

\section{Impact of the Rose Review}

The performance data in Figures 4 and 5 provides some evidence about the impact of phonics teaching post Rose. Figure 4 shows no effect on reading performance at the end of KS1 for the years 2008-2011. However, there is a suggestion in Figure 5 that then phonics teaching might have fed forward into performance at the end of KS2 from 2011 onwards. These pupils who would have all experienced a phonics programme from the start of their literacy 
education. Not surprisingly, there was still some concern about the tail of under achievement and the degree to which schools were secure in their provision of quality phonics teaching for KS1.

\section{The Phonics Screening Check}

In 2011, the DfE began developing a Phonics Screening Check (PSC). This was designed to give provide an objective measure of the ability of pupils to apply their phonics knowledge at the end of Y1. The check comprises 40 items: 10 easier regular words and 10 easier nonwords, followed by 10 more challenging regular words including some bi-syllabic words and 10 more challenging nonwords. All nonwords are paired with pictures of aliens to signal that these are not real. Trialling data on performance on possible items led to a difficulty gradient of item structure and an initial threshold of 32 correct. The difficulty gradient and threshold mark have remained the same in all iterations of the check, though the items vary year-on-year. Pupils who do not achieve the threshold in Y1 have to retake it at the end of Y2. The expectation is that those whose performance is below par will be given targeted support in $\mathrm{Y} 2$.

It would be disingenuous to say that the introduction of the PSC was not without controversy. Some related to a misunderstanding of the purpose of the PSC (e.g. Rosen, 2012; UKLA 2012). It is not intended as an assessment of reading. It is an assessment of ability to read regular words, and to use grapheme-phoneme correspondences: i.e. to apply knowledge learned in phonics lessons throughout the Reception and Y1. A purer form would have been to include only nonwords because it is not possible to interpret whether regular real words are read by application of GPC knowledge or by whole-word recognition. However, this would have been politically unwise and would have risked alienating many teachers.

[Figure 6 about here] 
Figure 6 shows the percentage of pupils meeting the threshold in all iterations of the PSC. The percentages for Y2 are those pupils who achieved the threshold in Y1 plus those who subsequently achieve it one year later. The percentage meeting the threshold in Y1 in 2012 was only $58 \%$. This was evidence that phonics teaching was not as successful as it should have been. This percentage then rose until it has now plateaued at just above $80 \%$. The extra targeted work in Y2 had an effect since, in 2013, half of the pupils who were below threshold achieved it at the end of KS1. However, these results mean that around $10 \%$ of pupils enter KS2 with poor word reading skills, and schools should recognise that just achieving the threshold or slightly above it in Y2 means those pupils are one year behind in their word reading.

Returning to Figure 4, from 2012 to 2015 there was a steady rise in performance in KS1 with percentages rising to $90 \%$ achieving Level 2. This coincides with the introduction of the PSC. Figure 5 shows a similar rise in the performance in KS2. Unfortunately, due to the change in assessment since 2016, it is not possible to interpret trends at the current time.

\section{Progress in International Reading Literacy Studies (PIRLS)}

Since 2001 there have been four international studies investigating reading conducted by the International Association for the Evaluation of Educational Achievement (IEA) (Mullis et al., 2003, 2007, 2012, 2017. PIRLS is a wide ranging and in-depth programme. Reading tasks centre on reading with understanding a range of texts from different genres, and answering questions relating to these.

Participating countries select a sample of pupils aged around 10 years to take part. The pupils from England are in Year 5: i.e. three years after they leave KS1 and one year before the end of KS2. England participated in all studies, so there is external data against which the national events discussed here can be mapped 
Figure 7 shows the overall mean performance, the levels of those at the $10^{\text {th }}$ and $90^{\text {th }}$ percentiles, and the median for PIRLS overall. The PIRLS centre point is 500, but medians are reported here because these counterbalance any skew from the economically advantaged nations.

[Figure 7 about here]

There appeared to be much to celebrate in the England PIRLS 1 performance levels. The average score placed it as third in the overall ranking. Pupils above the $90^{\text {th }}$ percentile achieved the best in the study. These children had received their early literacy instruction before the introduction of the NLS. However, the attainment gap between the $90^{\text {th }}$ and the $10^{\text {th }}$ centile (Figure 8 ) was higher than the PIRLS average and indicated that there was a tail of underachievement.

[Figure 8 about here]

The picture was not so rosy in 2006. England dropped to $19^{\text {th }}$ and there with a significant drop in the average level of performance. These pupils had received their literacy instruction under the NLS. The attainment gap was still wide: a worrying picture since the international gap had closed significantly and was significantly smaller than England's.

In 2011, average performance rose, and England was equal $11^{\text {th }}$. These pupils began school in 2007 so had received all their instruction post-Rose. The attainment gap had been closed slightly, but there was still evidence of the tail of underachievement.

In the latest PIRLS average performance rose to where it was 15 years earlier and was significantly higher than in 2006 and 2011 with pupils in the $90^{\text {th }}$ percentile again amongst the best in the world. Good news was that the attainment gap has been significantly reduced. The average improvement score overall can be accounted for by improvements of the lowest performing pupils. This 2011 cohort had received all their instruction post-Rose, and 
specifically they were the first whose word reading was assessed using the PSC. The correlation between PSC and PIRLS was a moderate statistically significant .52. The average PIRLS score for those pupils achieving 32 or above on the PSC was 587: 28 above the overall mean. The average score for pupils who achieved $100 \%$ on the PSC was 617 . A tentative interpretation of this is that introduction of the PSC has led to more effective phonics teaching, which has led to enhanced word reading, which in turn means pupils and teachers are able to focus their energy and enthusiasm on enjoying and understanding texts. Hence improved performance on the PIRLS assessments.

The evidence about teaching phonics is that it is most effective at the start of instruction and particularly helpful for those pupils who are at risk. The data from PIRLS 2016 support this. The requirement to teach systematic synthetic phonics as the first approach to word reading seems to be having a positive effect overall and to be particularly effective for those pupils who might otherwise have struggled in the early years.

\section{Teacher subject knowledge}

A theme running through Ofsted and OISE reports was the patchy level of teachers' subject knowledge about how children read words and why phonics is an effective approach. This issue remains. Trainee primary teachers have to learn how to teach phonics, but the majority of them have just one year's course to learn all aspects of teaching young children. There is a tendency to ignore the fact that most adults are not explicitly phonemically aware (Moats, 1994; Stainthorp, 2004) and need practice to raise their explicit phonemic awareness to a high enough level to teach phonics. There is evidence that some teachers are unaware of their lack of subject knowledge and skills, or over-estimate what they do know (Cunningham et al., 2004; Cunningham, Zibulsky, \& Callahan, 2009). After the introduction of the PSC, the DfE funded a series of day training sessions for teachers in areas where there was significant 
underachievement to provide them with the research underpinning of why to teach phonics as well as how to teach it. Feedback from roadshows delivered by the University of Reading provided evidence about why such training is needed. After taking part in the training participants were asked what they were most likely to take back to their schools. The top four things were: the importance of staff training and of monitoring practice following training; the need for practice to be consistent; the need to enhance staff subject knowledge; and the need to assess pupil progress in acquiring phonic knowledge more regularly (Flynn et al.).

\section{What have we learnt?}

In the last 20 years the landscape for teaching reading in England has completely changed. The research evidence about effective phonics teaching has fed into teaching practices, and is now sufficiently embedded such that all primary teachers have some expertise. The reduction in the tail of underachievement is something to be celebrated. Combined with a more fully specified PoS and evidence from performance on the PSC, teachers can now identify those children who are at risk sufficiently early to ensure in-class intervention can be provided in Y2. Where there are persistent difficulties, any subsequent interventions and assessments can be carried out in the knowledge that pupils with difficulties will have received explicit focused instruction.

This case study provides an account of what one country has done: it is not a blueprint. Phonics teaching is now embedded and having a positive effect. The PSC provides teachers with evidence about how well pupils have learnt and where some are struggling. This enables them to instigate early support. There remains a danger that phonics teaching is seen as sufficient in terms of teaching reading. The evidence is that it is necessary but not 
sufficient. The SVR remains the framework for teachers and should ensure they provide teaching that develops both word reading and comprehension.

In 2002 Willows wrote:

Training teachers to implement instructional methods when they don't truly understand the underlying rationale is futile. Without understanding teachers do not have the knowledge to adapt an instructional strategy to address various student needs. Without understanding teachers become cogs in a machine, with neither the responsibility nor the rewards of being in control. Without understanding teachers can become inflexible and dogmatic: unable to integrate new research-supported practices into existing approaches (Willows, 2002, p.1).

This is as true now as it was then. PIRLS 4 has provided objective evidence of a rise in performance possibly due to phonics teaching and assessment. The proof of the pudding will come with data from PIRLS 5 in 2021.

Acknowledgements: None

Financial support: This research received no specific grant from any funding agency, commercial, or not-for-profit sectors.

Conflicts of interest: None

Ethical standards: No human or animal experimentation was involved in this report. 


\section{References}

Brooks, G. (1997). Trends in standards of literacy in the United Kingdom, 1948-1996. Paper presented at UK Reading Association conference, University of Manchester, 1997

Christensen, C. A., \& Bowey, J. A. (2005). The efficacy of orthographic rime, graphemephoneme correspondence, and implicit phonics approaches to teaching decoding skills. Scientific Studies of Reading, 9, 327-349.

Clay, M. M., \& Cazden, C. B. (1990). A Vygotskian interpretation of reading recovery, in L. Moll (Ed.) Vygotsky and Education. New York: Cambridge University Press pp. 206222.

Coltheart, M., Rastle, K., Perry, C., Langdon, R., \& Ziegler, J. C. (2001). DRC: a dual route cascaded model of visual word recognition and reading aloud. Psychological Review, $108,204-256$

Cunningham, A. E., Perry, K. E., Stanovich, K. E., \& Stanovich, P. J. (2004). Disciplinary knowledge of K-3 teachers and their knowledge calibration in the domain of early literacy. Annals of Dyslexia, 54, 139-167.

Cunningham, A. E., Zibulsky, J., \& Callahan, M. D. (2009). Starting small: Building preschool teacher knowledge that supports early literacy development. Reading and Writing: An Interdisciplinary Journal, 22, 487-510.

DfE. (2010). Phonics teaching materials: core criteria and the self-assessment process. Department for Education.

DfE (2013). English programmes of study: Key stages 1 and 2 National Curriculum in England. Retrieved from https://assets.publishing.service.gov.uk/government/uploads/system/uploads/attachment _data/file/335186/PRIMARY national curriculum - English 220714.pdf 
DfEE Standards and Effectiveness Unit (1998). The national literacy strategy: Framework for teaching. HMSO.

DfEE Standards and Effectiveness Unit (1999). Progression in phonics: materials for wholeclass teaching. HMSO.

DfES. (2007). Letters and Sounds: principles and practice of high quality phonics. DFES00281-2007. DfES.

Earl, L., Fullan, M., Leithwood, K., \& Watson, N. (2000). OISE/UT Evaluation of the implementation of the National Literacy and Numeracy Strategies. Summary: First annual report. Watching \& learning. DfES.

Earl, L., Levin, B., Fullan, M., Leithwood, K. \& Watson, N. (2001). Watching and learning 2. DfES.

Earl, L., Watson, N., Levin, B., Leithwood, K., Fullan, M., \& Torrance, N. (2003). Watching and learning 3: Final report of the external evaluation of England's National Literacy and Numeracy Strategies. DfES.

Ehri L. C. (1995). Phases of development in learning to read words by sight. Journal of Research in Reading, 18, 116-125.

Ehri, L. C. (1999). Phases of development in learning to read words. In J. Oakhill \& R. Beard (Eds.), Reading, development and the teaching of reading: A psychological perspective (pp. 79-108). Blackwell Science.

Ehri, L. C. (2002). Phases of acquisition in learning to read words and implications for teaching. In R. Stainthorp \& P. Tomlinson (Eds.), Learning and teaching reading (pp. 7-28). British Journal of Educational Psychology Monograph Series II: Part 1. British Journal of Educational Psychology 
Flynn, N., Stainthorp, R., Powell, D., \& Stuart, M. (submitted). Training teachers for phonics and early reading: developing research-informed practice.

Gough, P. B., \& Tunmer, W. E. (1986). Decoding, reading and reading disability. Remedial and Special Education, 7, 6-10.

Hatcher, P. J., Hulme, C., \& Snowling, M. J. (2004). Explicit phoneme training combined with phonic reading instruction helps young children at risk of reading failure. Journal of Child Psychology and Psychiatry, 45, 338-358.

Johnston, R. S., \& Watson, J. (2005). The effects of synthetic phonics teaching on reading and spelling attainment: A seven-year longitudinal study. Edinburgh, Scotland: Scottish Executive Education Department. https://www.scotland.gov.uk/library5/education/sptrs-00.asp

Moats, L. (1994). Knowledge of language. Annals of Dyslexia, 44, 81-102.

Mullis, I.V.S., Martin, M.O., Foy, P., \& Drucker, K.T. (2012). PIRLS 2011 International results in reading. TIMSS \& PIRLS International Study Center, Boston College.

Mullis, I. V. S., Martin, M. O., Foy, P., \& Hooper, M. (2017). PIRLS 2016 International results in reading. Boston College, TIMSS \& PIRLS International Study Center website. https://timssandpirls.bc.edu/pirls2016/international-results/

Mullis, I.V.S., Martin, M.O., Gonzalez, E.J., \& Kennedy, A.M. (2003). PIRLS 2001 International Report: IEA's study of reading literacy achievement in primary schools. Boston College.

Mullis, I.V.S., Martin, M.O., Gonzalez, E.J., \& Kennedy, A.M, \& Foy, P. (2007). PIRLS 2006 International Report: IEA's progress in international reading literacy study in primary school in 40 countries.TIMSS \& PIRLS International Study Center, Boston College. 
NICHHD (2000). Report of the National Reading Panel: Teaching children to read: an evidence-based assessment of the scientific research literature on reading and its implications for reading instruction : reports of the subgroups. National Institute of Child Health and Human Development, National Institutes of Health.

OFSTED (1996). Teaching of reading in 45 London primary schools. HMSO

Rose, J. (2006). Independent review of the teaching of early reading final report. U.K. Department for Education and Skills. https://dera.ioe.ac.uk/5551/2/report .pdf

Rosen, M. (2012). This summer's phonics test is not a reading test [Blog post]. Retrieved from http://michael rosenblog.blogspot.com.au/2012/04/this-summers-phonics-test-isnot.html

Rowe, K. (2005). Teaching reading: National inquiry into the teaching of literacy.

Department of Education, Science and Training, Australian Council for Educational Research. https://research.acer.edu.au/tll_misc/5/

Stainthorp, R. (2004). W(h)ither phonological awareness? Literate trainee teachers' lack of stable knowledge about the sound structure of words. Educational Psychology, 24, 753-766.

UK Literacy Association (2012). Phonics Screening Check fails a generation of able readers. https://ukla.org/news/story/phonics screening check fails a generation of able read $\underline{\text { ers/ }}$

Willows, D. M. (2002). The balanced literacy diet. The School Administrator, 59, 30-33. 
Appendix A

\begin{tabular}{|c|c|}
\hline $\begin{array}{l}\text { NC PoS } 1999 \\
\text { Reading strategies } \\
\text { KS1 } \\
1 \text { To read with fluency, accuracy, } \\
\text { understanding and enjoyment, pupils should } \\
\text { be taught to use a range of strategies to } \\
\text { make sense of what they read. They should } \\
\text { be taught to: } \\
\text { Phonemic awareness and phonic knowledge } \\
\text { a hear, identify, segment and blend } \\
\text { phonemes in words } \\
\text { b sound and name the letters of the } \\
\text { alphabet } \\
\text { c link sound and letter patterns, exploring } \\
\text { rhyme, alliteration and other sound } \\
\text { patterns } \\
\text { d identify syllables in words } \\
\text { e recognise that the same sounds may have } \\
\text { different spellings and that the same } \\
\text { spellings may relate to different sounds } \\
\text { Word recognition and graphic knowledge } \\
\text { f read on sight high-frequency words and } \\
\text { conventions, structure, sequence and } \\
\text { other familiar words } \\
\text { g recognise words with common spelling } \\
\text { pontextual understanding } \\
\text { focus on meaning derived from the text } \\
\text { a recognise specific parts of words, } \\
\text { including prefixes, suffixes, inflectional } \\
\text { endings, plurals } \\
\text { Grammatical awareness } \\
\text { i understand how word order affects } \\
\text { meaning } \\
\text { check meaning }\end{array}$ & $\begin{array}{l}\text { Reading- word r } \\
\text { Y1 } \\
\text { Pupils should b } \\
\text { - apply phonic } \\
\text { route to decoc } \\
\text { - respond speed } \\
\text { to graphemes } \\
\text { letters) for all } \\
\text { where applica } \\
\text { graphemes } \\
\text { - read accuratel } \\
\text { unfamiliar wo } \\
\text { have been tau } \\
\text { - read common } \\
\text { unusual corre } \\
\text { spelling and s } \\
\text { occur in the w } \\
\text { read words co } \\
\text {-s, - es, -ing, } \\
\text { read other wo } \\
\text { syllable that c } \\
\text { read words wi } \\
\text { example, I'm, } \\
\text { understand th } \\
\text { represents the } \\
\text { read aloud acc } \\
\text { consistent wit } \\
\text { knowledge an } \\
\text { to use other st } \\
\text { re-read these } 1 \\
\text { Pluency and cc } \\
\text { in words that } \\
\text { taught so far, } \\
\text { alternative sol } \\
\text { continue to ap } \\
\text { skills as the ro } \\
\text { automatic dec } \\
\text { embedded anc }\end{array}$ \\
\hline
\end{tabular}




\begin{tabular}{|c|c|}
\hline $\begin{array}{l}\mathrm{n} \text { draw on their background knowledge } \\
\text { and understanding of the content }\end{array}$ & $\begin{array}{l}\text { read accurately words of two or more } \\
\text { syllables that contain the same } \\
\text { graphemes as above } \\
\text { - } \text { read words containing common suffixes } \\
\text { read further common exception words, } \\
\text { noting unusual correspondences between } \\
\text { - } \text { spelling and sound and where these } \\
\text { occur in the word } \\
\text { - read most words quickly and accurately, } \\
\text { without overt sounding and blending, } \\
\text { when they have been frequently } \\
\text { encountered } \\
\text { - read aloud books closely matched to } \\
\text { their improving phonic knowledge, } \\
\text { sounding out unfamiliar words } \\
\text { accurately, automatically and without } \\
\text { undue hesitation } \\
\text { re-read these books to build up their } \\
\text { fluency and confidence in word reading. }\end{array}$ \\
\hline
\end{tabular}


Figure 1: Timeline of events

Figure 2: Structure of the Literacy Hour

Figure 3: The Searchlights Model

Figure 4: Percentage of pupils achieving Level 2 in Reading at the end of Key Stage 1(Working at Expected Level from 2016)

Figure 5: Percentage of pupils achieving Level 4 in Reading at the end of Key Stage 2 (Working at Expected Level from 2016)

Figure 6: Percentage of pupils achieving 32 in the Phonics Screening Check

Figure 7: PIRLS mean scores for England and the PIRLS countries with performance levels at the $10^{\text {th }}$ and $90^{\text {th }}$ percentiles

Figure 8: PIRLS attainment gaps between the $90^{\text {th }}$ and $10^{\text {th }}$ percentiles for England and total participating countries 
Figure 1: Timeline of Events

\begin{tabular}{|l|l|}
\hline 1986 & $\begin{array}{l}\text { Education Reform Act } \\
\text { National Curriculum begins } \\
\text { Key Stage Assessments begin: Levels of Attainment described }\end{array}$ \\
\hline 1995 & Only 49\% of pupils achieved Level 4 in English at the end of Key Stage 2 \\
\hline 1996 & Ofsted reports concerns about levels of literacy \\
\hline 1997 & National Literacy Strategy (NLS) introduced \\
\hline 1999 & Progress in Phonics published \\
\hline 2000 & $\begin{array}{l}\text { USA } \\
\text { National Reading Panel Report: Teaching Children to Read }\end{array}$ \\
\hline & $\begin{array}{l}\text { Canada } \\
\text { OISE report on the NLS Watching and Learning 1 }\end{array}$ \\
\hline Progress in Reading Literacy Study (PIRLS 1) \\
\hline 2001 & $\begin{array}{l}\text { Canada } \\
\text { OISE report on the NLS Watching and Learning 2 }\end{array}$ \\
\hline 2003 & $\begin{array}{l}\text { Canada } \\
\text { OISE report on the NLS Watching and Learning 3 }\end{array}$ \\
\hline $\begin{array}{l}\text { Australia } \\
\text { Teaching reading: National inquiry in the teaching of literacy for the } \\
\text { Department of Education, Science and Training (Rowe) }\end{array}$ \\
\hline $\begin{array}{l}\text { Independent Review into the Effective Teaching of Early Literacy (Rose } \\
\text { Review) }\end{array}$ \\
\hline 2006 & PIRLS 2 \\
\hline Letters and Sounds published \\
\hline PIRLS 3 \\
\hline Phonics Screening Check end of Y1 starts \\
\hline New National Curriculum \\
\hline 2011 & $\begin{array}{l}\text { Wevels of Attainment abolished } \\
\text { Working at Expected Level introduced (descriptors changed) }\end{array}$ \\
\hline
\end{tabular}

Figure 1: Timeline of Events 


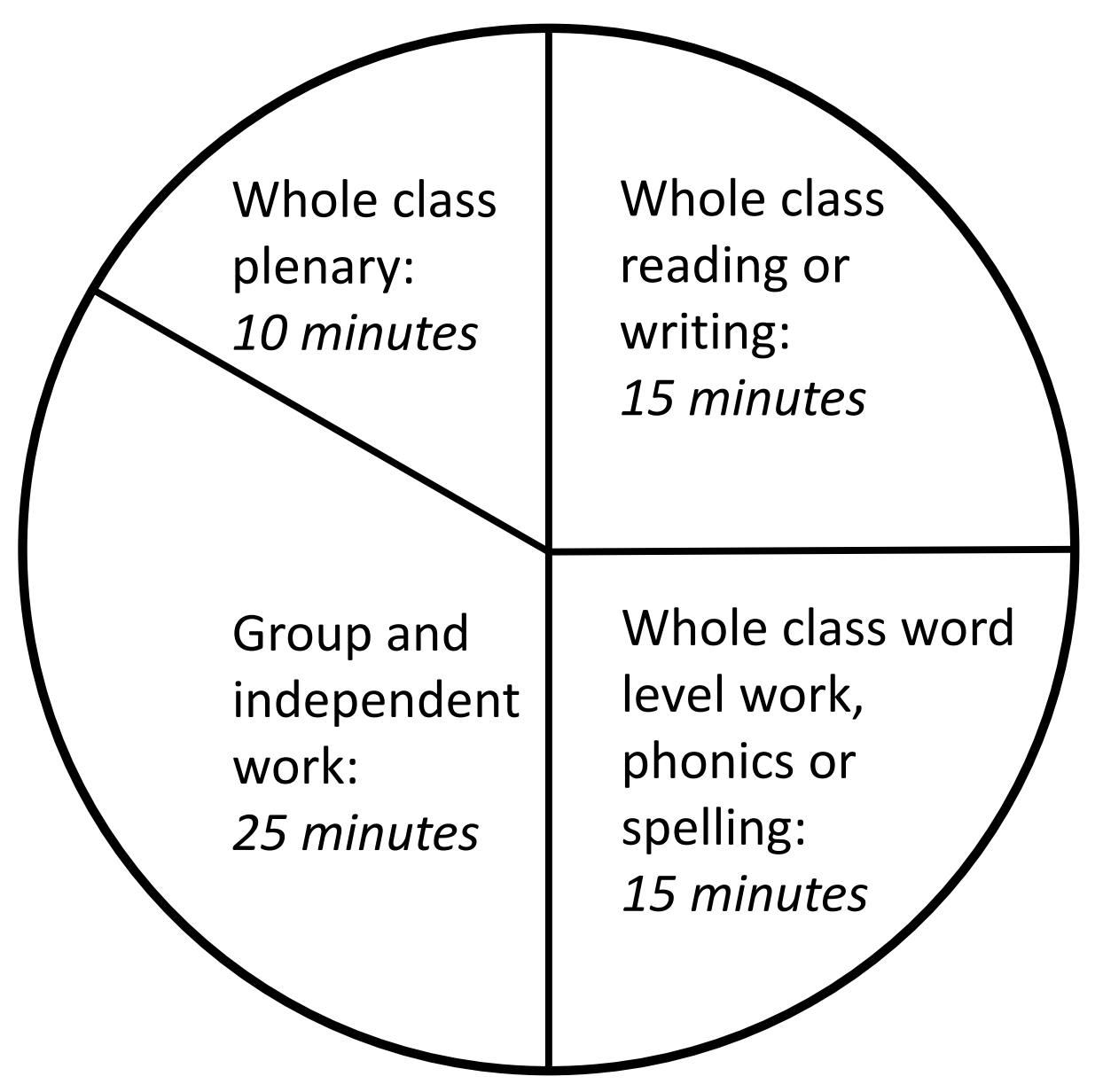

Figure 2: The structure of the literacy hour 


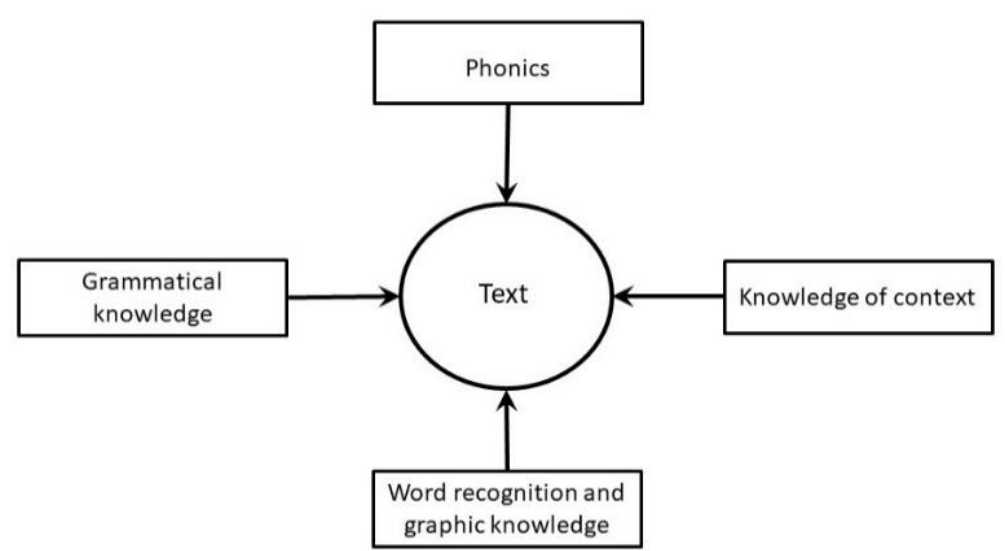

Figure 3: The searchlights model 


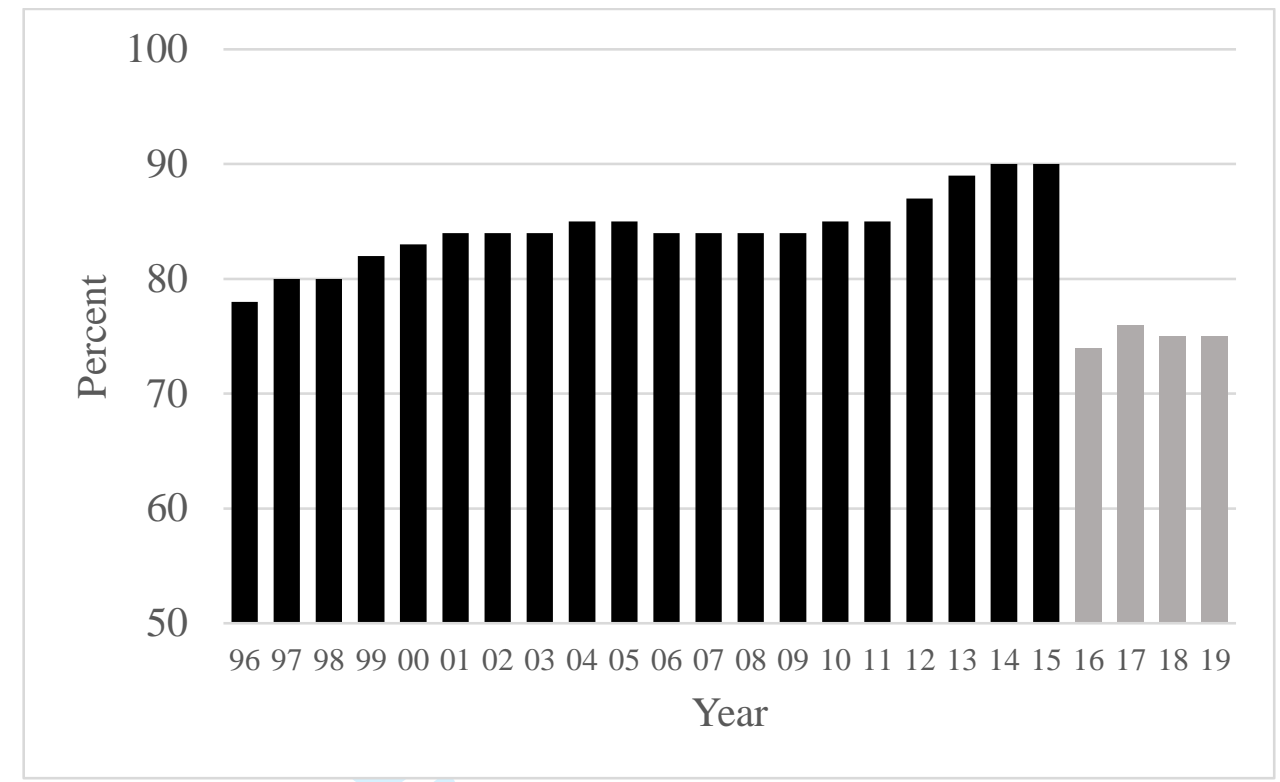

Figure 4: Percentage of pupils achieving Level 2 in reading at the end of Key Stage 1(Working at Expected Level from 2016) 


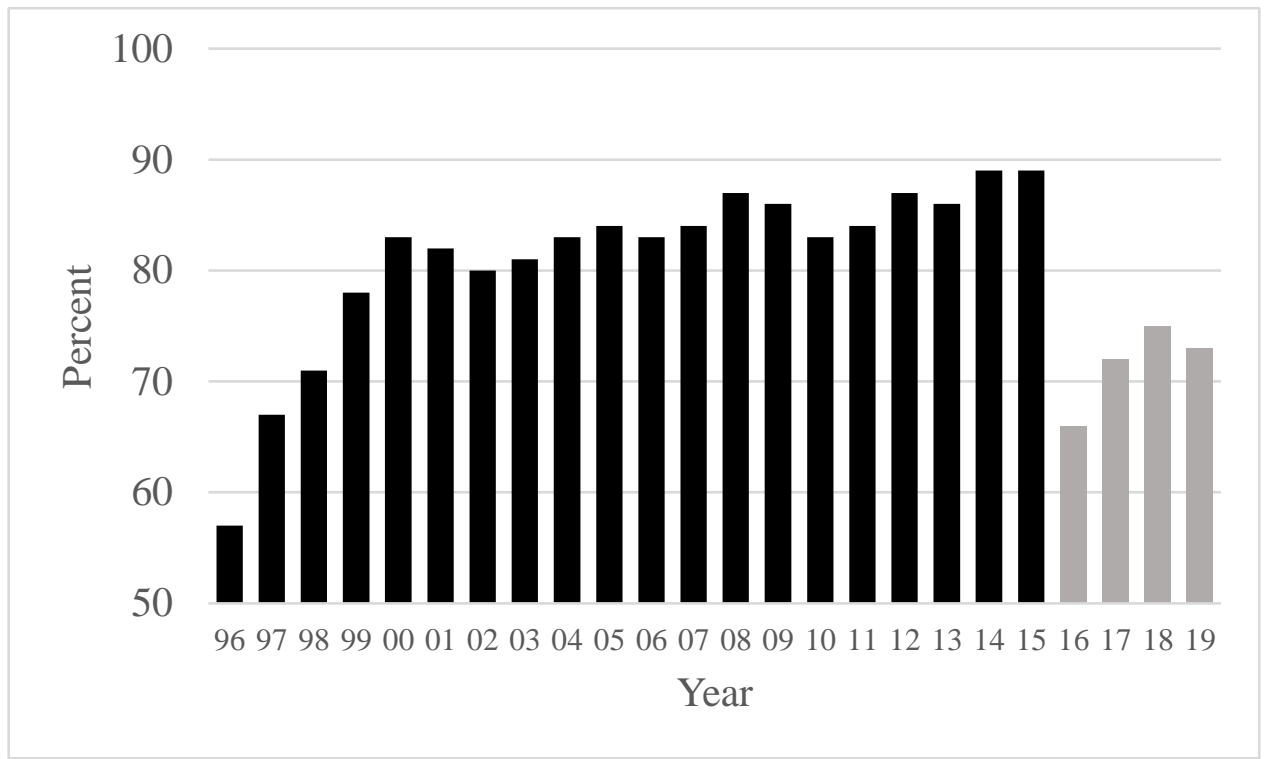

Figure 5: Percentage of pupils achieving Level 4 in reading at the end of Key Stage 2 (Working at Expected Level from 2016) 


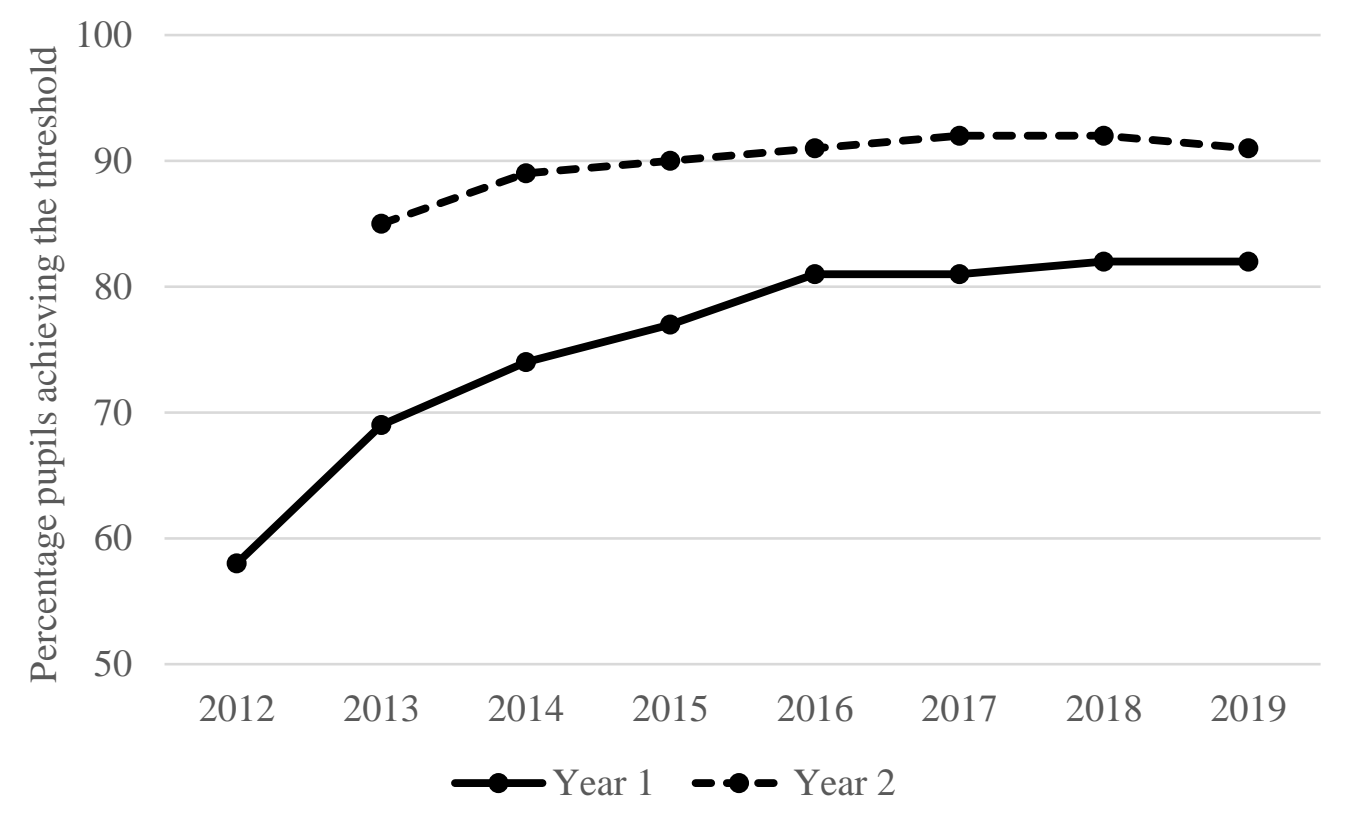

Figure 6: Percentage of pupils achieving 32 in the Phonics Screening Check 


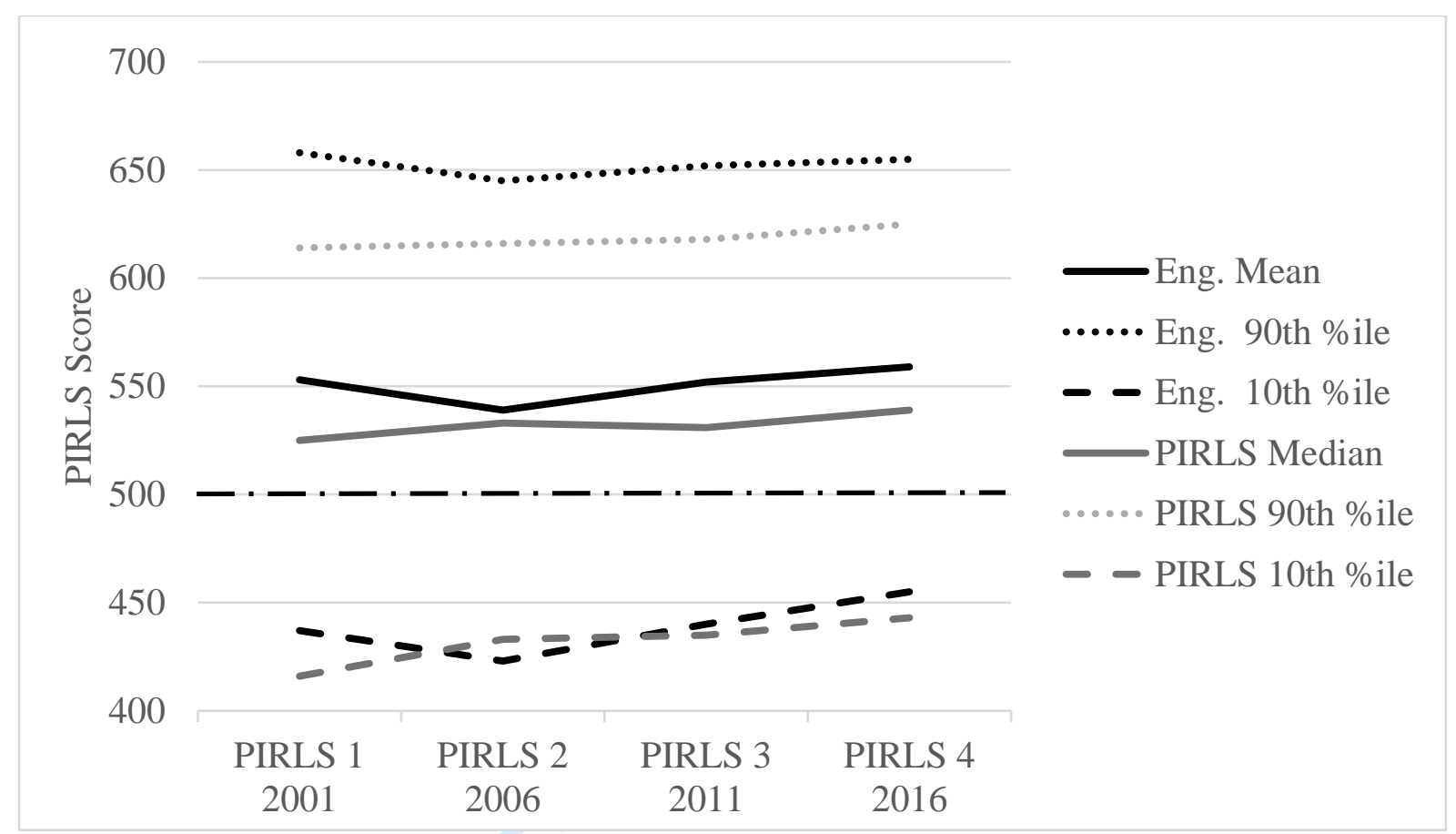

Figure 7: PIRLS mean scores for England and the PIRLS countries with performance levels at the $10^{\text {th }}$ and $90^{\text {th }}$ percentiles. 
250

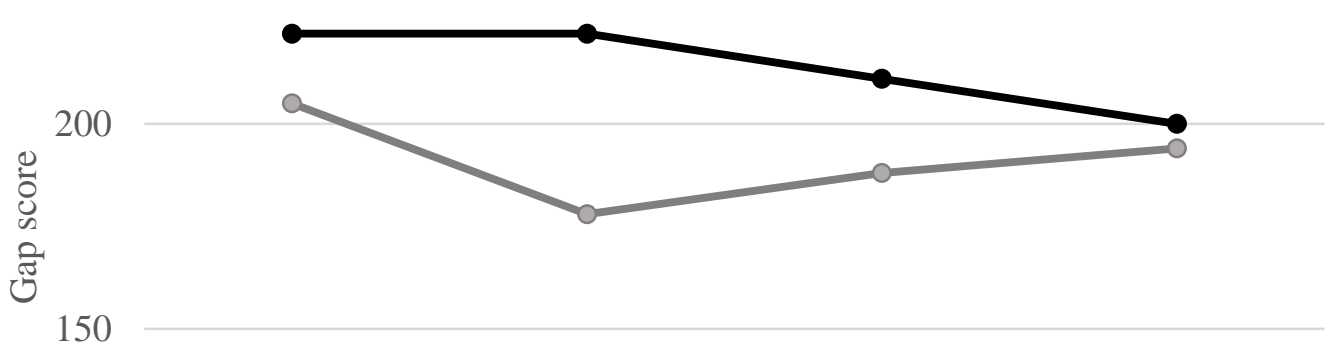

150

100

$$
\text { PIRLS } 12001 \quad \text { PIRLS } 22006 \quad \text { PIRLS } 32011 \quad \text { PIRLS } 42016
$$

$\rightarrow$ England $\rightarrow$ PIRLS

Figure 8: PIRLS attainment gaps between the $90^{\text {th }}$ and $10^{\text {th }}$ percentiles for England and total participating countries 